had been incised two letters belonging to the early South Arabic script. This is assigned by strati. graphic evidence to approximately the latter part of the eighth century в.c. The letters are the earliest known to bo definitely datable from a scientifically controlled excavation. Dr. Nelson Glueck, director of the School, in a preliminary account of the excavations carried out in May-June, 1939 (Illus. trated London Neus of August 5) records the dis. covery of an ingenious and complicated system of flues and chnnnels in the thick and high walls of sun-dried brick of the first city, which is so con. structed as to utilize the draught of the prevailing winds from the north for the furnaces of an elaborate complex of smelting and refining plant-the largest yet discovered in the ancient Near East. 'This system would appear to havo been the governing factor in determining the site for the first city ; and so well bonded were the bricks that many of the walls still stand almost at their original height after nearly three thousand years. Among smaller finds from the third city were Egyptian amulets, of which one was a small cat, a form characteristic of the cult of the goddess Bast of Bubastis, and another was the Uzat eye of Horus.

\section{Jenner and Napoleon}

AT a recent meeting of the Section of the History of Medicine of the Royal Society of Medicine (Proc. Roy. Soc. Med., 32, 877; 1939), Dr. J. A. Nixon said that the world.wide eminence of Edward Jenner found no better illustration than his ability to secure the liberation of British prisoners from countries with which England was at war. Ono of the best known of these prisoners was the Earl of Yarmouth, the model of 'Thackeray's Marquess of Stoyno and Disraeli's Marquess of Monmouth, on behalf of whom Jenner addressed in 1803 the following appeal to the National Institute of France: "The Sciences are never at war. . . Permit mo then as a public body with whom I am connected to solicit the exertion of your interest in the liberation of Lord Yarmouth". In 1805 Jenner addressed himself directly to Napoleon requesting that two of his friends, Mr. William Thomas Williams and J)r. John Wickham, both men of scienco and literature, might return to England. According to Baron, the well-known biographer of Jenner, it was either on this or a similar occasion that Napoleon exclaimed: "Jenner! Ah, we can refuse nothing to this man." Jenner was also successful in obtaining the release of Sir George Sinclair, who had been arrested us a spy at Góttingen. J3esides helping to liberate Englishmen detained on tho Continent, Jenner issued certificates stating that travellers abroad wero known to him and wero undertaking a voyage in pursuit of science or health or other affairs entirely unconnected with the war, and were in his opinion entitled to protection and freedom.

\section{British School of Archæology at Athens, 1935-36}

Altrougn the Annual of the British School at Athens no longer provides a general view of the activities of the School and its students- information which now must be sought in a separate publication-its contents continuo to record the more important operations of its members. The volume for 1935-36 (London: Macmillan and Co., Ltd., 1939. 42s. net), however, opens with an account, very fully illustrated, by Dr. Alex. Phila. delphus, director of the National Iruseum of Athens, of the Anavysos Kouros, a remarkable example of archaic art, in fact "one of the most perfect and almost the last link in the long chain of Apollos or kouroi that have como down to us", probably. dating at about 530 в.c. This statue, which was recovered in fragments from an antiquo dealer in Paris, had been smuggled out of Greece by sea a few years ago from Anavysos, near Laurium. Of the remainder of the contents of the volume the greater part is given up to the excavation of tho cave of Trapeza on the plain of Lasithi in eastern Crete. This cavo was first discovered by Sir Arthur Fvans in 1896, who refers to it as containing objects mainly of the Hellenistic period, but also a faienco figure of Bes and fragments of gold leaf, which afterwards found a parallel in the Early Minoan jowellery at Mokhlos. Apart from mention by Tara. melli and Bosanquet, it received no attention from archaologists until 1935, when it was visitcd by members of the School. In 1936, between May 4 and 19, it was excavated by Miss Money-Coutts, Mr. and Mrs. J. D. S. Pendlebury and others. Judging from the funds, the contents of the cave originally must have been rich. Although metal was comparatively rare, gold, silver, bronze (or copper), and lead were all repre. sented. The deposits in the cave, however, had been much disturbed by treasuro hunters, and in ono spot only were they intact. It has, therefore, been possiblo to study the pottery found for the most part on stylistic evidence only, and to reconstruct the history of the cave accordingly. It would appear to have been occupied as a habitation sito in Inato Neolithic, and to have been used for communal interment from Farly Minoan II until the end of Early Minoan III.

\section{The Cyclotron and Biological and Medical Research}

Dr. G. E. Hakrisos, lecturer in physics, in the University of Birningham, has been elected to a Rockefeller Foundation fellowship in natural science which will enable him to spend a year at Berkeley University, California, studying under Profs. J. H. and E. O. Lawrence. The object of the risit is to acquire first-hand knowledge of the application of neutrons to biological and therapeutic research, in which the Profs. Lawrence have opened up a new field the exploration of which seems likely to be of first-rate importance in the treatment of disease. Berkeley University, whero Prof. Lawrence con. structed his cyclotron and has doveloped his own technique, is unique in facilities for the production of neut rons and artificinl radioactivo substances. When the large cyclotron which I'rof. Oliphant is building for research in nuclear physics in the Physics Department of the University of Birmingham is completed, this University, in which the Physics Department and new Medical School aro in closo proximity, will 
be in an exceptionally favourable position for the promotion of the therapeutic and physiological in. vestigations which Prof. Lawrence at Berkeley and Prof. Hevesy at Copenhagen have so strikingly originated. It is hoped that on his return from California, Dr. Harrison will organize and direct research in these subjects in the University of Birmingham.

\section{The Ontario Research Foundation}

THE report of the Ontario Research Foundation for the year 1938 (Sessions Paper, No. 48, 1939. Pp. 36. Toronto : King's Printer, 1939) refers to the extension of the soil survey of the central part of Southern Ontario eastward to the Quebec border. The Department of Agriculture has also determined the general relations between the performance of certain varieties of apple, and climatic and soil conditions in the apple-growing sections of the Province. The Department of Pathology and Bacteriology has continued its studies of bovine mastitis. Attention has been focused on the prevention of human infection by pasteurization of milk, and experimental work was continued during the year on Brucella Abortus. Studies relating to the sheep nose fly were continued during tho year as well as on the parasites of game and fish. The Textiles Department has been responsible for investigations on causes of fabric fraying and the quantitative and consistent measurement of this tendency. They have also been responsible for testing work on the fastness to light of dyestuffs used in the Canadian textile industry, and have commenced a study of the fundamental and physical characteristics of single silk fibres. The testing work and control work of the department, particularly in connexion with rayon merchandise, have also increased. The facilities of the Department of Engineering and Metallurgy for the investigation of products associated with airconditioning have been extended, and were put to considerable use in the year. A study of the resistance of metals and alloys to abrasion and wear has developed to a stage which permitted a new pro. gramme of work to be prepared, and results of tests on suitable metals have been collated.

The Department of Chemistry in its investigation of paint failures in the Paint and Varnish Laboratory has continued to yield information essential to understand the problem of protective finishes, and a fundamental investigation of the processing of drying oils is in progress. Other work on a low cost plastic moulding powder prepared from wood meal has overcome the difficulties due to the absence of some properties which are essential to commercial success, and a low cost powder is now available which can be moulded commercially. Interpolymerization of styrene and other organic chemicals has been studied in the cellulose and plastics laboratory and a new series of interpolymers developed which are notable in their resistance to swelling in commercial solvents. During the year an Analytical Laboratory was established to serve as a central Yaboratory in the
Foundation for analytical problems. The Paper, Printing and Adhesives Laboratory has worked mainly on packaging and adhesive problems due to difficulties through odours and moisture. In the Department of Biochemistry work on the production of lactic acid and other chemicals by the action of micro-organisms has been conducted, as well as pilot scale tannery operations to improve the vegetable chrome process for the manufacture of sole and belting leather which was developed in 1937, and in addition to improving the colour of the leather it is hoped to improve still further its durability under normal wearing conditions. Attention is also being given to the development of spue on finished leather, and a complete report on the technology and economics of pectin production has been prepared for one of the large apple growers of the Province.

\section{"Nomenclator Zoologicus"}

WE have received a sample part of the "Nomenclator Zoologicus", edited by Dr. S. A. Neave. of which the first volume is about to be published by the Zoological Society. The work, which will be completed in four volumes, aims at giving "as com. plete a record as possible of the bibliographical origins of the name of every genus and subgenus in zoology published since 1758 , the date of the tenth edition of Linnæus' 'Systema Naturæ', up to the end of the year 1935". Up to 1850, not only the generic but also the specific names are indexed in Sherborn's monumental "Index Animalium". Since that date, however, the scale of zoological publication has increased so vastly that a continuation of "Sherborn" would be a task of overwhelming magnitude. Even in the all-important matter of generic names the systematist has been compelled to spend much time and labour in tracing their origin and in trying to avoid re-inventing old names for new genera. The "Nomenclator Animalium generum et subgenerum" published by the Prussian Academy of Sciences, begun in 1926, was designed to remedy this state of affairs, but it has been making its appearance in so leisurely a fashion that, although already thirteen years out of date, it is not yet completed. Dr. Neave, who has had the assistance of the specialists on the staff of the British Museum (Natural History), as well as of many other zoologists in Great Britain and abroad, hopes to complete publication by the end of 1940 . A part from cross-references and variations in spelling, he and his collaborators have collected about 192,000 generic names, of which at least 5,000 have escaped inclusion in former nomenclators and in the "Zoological Record". No doubt many omissions remain to be discovered, and zoologists are asked to send a note of any they may find so that they may be included in a supplementary list at the end of the last volume.

\section{Forestry in South Africa}

WE welcome the issue of the first number of a new forestry publication appearing in the Journal of the South African Association (No. 1, Oct. 1938, Pretoria, published by the Association, April and 